\title{
Pola asuh oleh ibu pada balita dengan berat badan di Bawah Garis Merah (BGM) di Surabaya
}

\section{Parenting pattern by mother to toddler below the red line in Surabaya}

\author{
Novida D. Airinda \& Myrtati D. Artaria \\ Indonesian Resource Center for Indigenous Knowledge (UNRIK) \\ Universitas Padjajaran, Jl. Dipati Ukur no. 35 \\ Bandung \\ E-mail: novairinda@gmail.com
}

\begin{abstract}
Widely known as Asian rice producer in the past, Indonesia is still struggling with the issue of malnutrition until recent times. Growth and development of toddler are not maximal because their nutrition are not properly fulfilled since their early age. This research tries to explain mother's parenting pattern for toddler under the red line (bawah garis merah/BGM). The research was conducted in Kenjeran, District of Bulak, Surabaya, by interviewing and observing five informants. Data were analyzed by interview and observation, later to be interpreted. The research found that mother's knowledge about parenting and child's health are still influenced by belief that do not solve problem properly. Giving solid food to baby is a common thing and believed to resulted better than giving breast milk before their minimum age. This action is not medically recommended because baby has a minimum age to be able to digest solid food as complementer to breast milk.
\end{abstract}

Keywords: parenting pattern, toddler, under weight, child health, tradition

\begin{abstract}
Abstrak
Meskipun Indonesia pernah dikenal sebagai "Lumbung Padi Asia", namun pada kenyataannya fenomena gizi buruk tidak pernah selesai. Pertumbuhan dan perkembangan balita pun tidak maksimal sebab gizi mereka tidak terpenuhi di usia balita. Penelitian ini bertujuan untuk mengetahui pola asuh oleh ibu pada balita dengan berat badan di Bawah Garis Merah (BGM). Penelitian dilakukan di Kelurahan Kenjeran, Kecamatan Bulak, Surabaya, dengan mewawancara dan mengobservasi lima orang informan. Data dianalisis dari hasil wawancara dan pengamatan, untuk kemudian diinterpretasi. Hasil penelitian menunjukkan bahwa situasi sosial-ekonomi menuntut mereka agar ke dua orang tua bekerja, dan anak dititipkan pada orang lain. Dapat disimpulkan dari penelitian ini bahwa pengetahuan tentang pengasuhan dan kesehatan anak masih banyak diwarnai oleh kepercayaan yang tidak memecahkan masalah dengan baik. Praktik pemberian makanan padat pada bayi masih sering dilakukan di daerah ini, yang mana dipercaya lebih bagus dari pada pemberian ASI saja. Padahal secara medis hal ini tidak disarankan, karena bayi mempunyai umur minimal untuk dapat menerima makanan padat sebagai tambahan dari ASI.
\end{abstract}

Kata kunci: pola asuh, balita, Bawah Garis Merah, kurang gizi, tradisi

\section{Pendahuluan}

Salah satu pusat koordinasi tubuh yang paling penting adalah otak. Ini dibuktikan sejak manusia masih dalam di kandungan. Otak adalah organ yang paling cepat mengalami pertumbuhan daripada organ lainnya. Perkembangan otak tersebut cepat sejak dalam janin ibu hingga berusia 5 tahun (golden age). Holford, ilmuan dari Institute of Optimum Nutrition, Inggris, menegaskan 
bahwa kemampuan otak berfungsi optimal bergantung pada pasukan gizi dan asupan makanan setiap hari, sehingga otak tidak akan maksimal dan optimal pada balita penderita gizi buruk (Moehji 2003:10-11). Sudah menjadi keharusan bahwa para ibu tahu mengenai kebutuhan gizi balita, sebab ibu memiliki peran penuh terhadap kondisi balita sejak ia masih di dalam kandungan.

Meskipun Indonesia pernah dikenal sebagai "Lumbung Padi Asia", namun pada kenyataannya fenomena gizi buruk tidak pernah selesai. Pertumbuhan dan perkembangan balita pun tidak maksimal sebab gizi mereka tidak terpenuhi di usia balita. Berdasarkan data yang tercatat di Direktorat Bina Gizi Masyrakat, unit Eselon II Direktorat Jenderal Bina Kesehatan Masyarakat, Kementerian Kesehatan RI, terdapat empat provinsi yang selalu memiliki angka gizi buruk tertinggi tiap tahunnya. Provinsi Jawa Tengah, Jawa Timur, Nusa Tenggara Timur dan Gorontalo yang sepanjang 2005-2009. Provinsi NTT pada tahun 2005, 2007 dan 2008, menduduki posisi teratas sedangkan tahun 2006 dan 2009 masing-masing ditempati Jawa Tengah dan Jawa Timur.

Di Indonesia, pengurangan jumlah penderita jumlah penderita gizi buruk menjadi salah satu target Tujuan Perkembangan Milenium (Millenium Development Goals atau MDGs). Pemerintah berkomitmen untuk mengurangi hingga setidaknya tinggal $18 \%$ penduduk yang mengalami gizi buruk pada tahun 2015, di mana angka tahun 2008 masih $28 \%$.

Menurut (Arisman 2004) faktor yang mempengaruhi berat badan bayi yang baru lahir ditentukan oleh status gizi janinnya, disamping faktor genetis. Status gizi janin dapat ditentukan antara lain oleh status gizi ibu saat melahirkan berdasarkan keadaan sosial dan ekonomi waktu hamil, derajat pekerjaan fisik, asupan pangan, dan pernah tidaknya terjangkit infeksi. Begitu pula dengan perempuan yang terlalu sering hamil, dapat menguras cadangan zat gizi tubuh.

Masalah gizi jika tidak diatasi dengan segera maka besar kemungkinan akan berakibat fatal, yaitu kematian. Penelitian yang dilakukan di Pulau Kangean membuktikan bahwa karakteristik keluarga merupakan faktor yang secara teoritis paling penting dalam memberi pengaruh pada kejadian kematian bayi dan kematian anak (Purnomo 2002:139). Status gizi tidak dapat dipisahkan dengan penerapan pola asuh oleh orang tua dan lingkungan di mana anak tersebut dibesarkan. Ibu memiliki peran lebih besar dari seluruh anggota lainnya dalam pemenuhan kebutuhan nutrisi selama masa tumbuh kembang, ataupun intensitas perawatan kesehatan orang tua terhadap balita. Kepedulian ibu terhadap kesehatan dan tumbuh kembang anak diwujudkan dengan bagaimana ia merawat dan menjaganya. Karenanya kami ingin meneliti, bagaimana penerapan pola asuh yang dilakukan oleh orang tua pada balita berstatus Bawah Garis Merah (BGM)?

\section{Metode Penelitian}

Tipe penelitian ini adalah deskriptif. Penelitian ini bertujuan untuk mendeskripsikan secara terperinci fenomena-fenomena sosial atau gejala sosial yang berlangsung di lapangan, khususnya menggambarkan penerapan pola asuh orang tua terhadap kejadian balita Bawah Garis Merah (BGM). Penelitian dilakukan di Kelurahan Kenjeran, Kecamatan Bulak, Surabaya. Informan dalam penelitian ini adalah: A (45 tahun), pedagang makanan dan minuman ringan di Taman Hiburan Pantai (THP). Juhroh ibu dari Ade Maulana Putra (12 bulan), anak ketiga dari tiga bersaudara. B (40 tahun), seorang ibu rumah tangga. Maryam ibu dari Nurul Aini (57 bulan), anak keenam dari enam bersaudara. C (42 tahun), seorang penjahit busana. Mahjuro ibu dari Marisa Dwi Artanti (22 bulan), anak kedua dari dua bersaudara. D (36 tahun), seorang ibu rumah tangga yang memiliki toko kelontong di rumah. Endang ibu dari Gabriella Suci Okta (30 bulan), 
anak keenam dari enam bersaudara. E ( 25 tahun), seorang pengasap ikan. Sunariyah ibu dari anak tunggalnya, Sani Wulan Agustina (32 bulan).

Kelima informan adalah orang tua sekaligus pengasuh balita dengan status BGM sejak 5 bulan terakhir. Data balita BGM semula diperoleh dari ketua kader posyandu RW, mulai RW I sampai RW IV. Pengumpulan data di lapangan dilakukan dengan metode observasi/pengamatan dan wawancara. Data-data tersebut dikelompokkan berdasarkan tema dan sub tema yang dituliskan dalam penelitian, kemudian akan dianalisis dengan menghubungkannya dengan kerangka pemikiran yang telah dibuat sebelumnya. Analisis data dilakukan secara deskriptif kualitatif dan mengacu pada kerangka teori dan masalah penelitian. Data yang sudah dianalisis kemudian akan diinterpretasi.

\section{Hasil Penelitian dan Pembahasan}

Ibu memiliki waktu lebih banyak dengan anaknya dibanding anggota keluarga yang lain. Ibu pula yang bertanggungjawab secara langsung terkait kesehatan keluarga, termasuk anak-anaknya. Saat anak sakit, ibu dituntut agak bertindak tepat agar anaknya segera kembali pulih kesehatanyya. Begitu pun saat anaknya sehat, ibu lah yang menjaga anak-anaknya agar tidak mudah sakit. Oleh karena itu, ibu melaksanakan tugasnya sebagai pengasuh anak sering kali butuh bantuan dari orang lain. Baik orang tuanya, anaknya yang lebih tua, atau tetangga.

Umumnya para ibu yang memiliki balita BGM tidak hanya berperan sebagai ibu rumah tangga, mereka juga memiliki pekerjaan lain baik di dalam rumah atau di luar rumah yang rutin setiap hari. Hal ini yang membuat mereka harus membagi waktu antara tuntutan pekerjaan dan mengasuh balitanya. Informan B, C, D, dan E adalah ibu yang memiliki pekerjaan lain di luar urusan rumah tangga, sedangkan informan $\mathrm{A}$ adalah ibu rumah tangga yang sesekali menerima pekerjaan lain. Membiarkan anak-anak bermain di luar rumah menjadi hal yang biasa di Kenjeran. Seperti kutipan wawancara peneliti dengan informan A berikut:

“.......banyak, mbak. Saudara-saudara, tetangga, orang sini juga biasa kalau anakanaknya main sama teman-teman sebayanya ke rumah. Ya, hampir sama semua oranglah. Nurul juga, kan anaknya gak terlalu pemalu."

Informan A membiasakan balitanya agar lebih dekat dengan saudara-saudara dan tetangganya. Bahkan, informan A merasa senang jika balitanya akrab dengan siapa saja, agar nanti anaknya tidak tumbuh sebagai anak perempuan yang pemalu. Pada pagi hari informan A memberi izin balitanya untuk bermain dengan teman-temannya dan mengunjungi kakek dan pamannya. Biasanya, saat balitanya sedang tidak di rumah informan A akan melakukan pekerjaan rumah tangga seperti menyapu, mengepel, dan mencuci baju. Balita tersebut akan kembali ke rumah siang atau sore hari. Saat balitanya pulang, informan A akan memandikan, menyuapi makan, dan menidurkannya. Praktis, ia akan menjaga penuh balita tersebut mulai sore sampai esok pagi.

Saat informan tidak dapat menjaga balitanya karena bekerja, balita tersebut sering kali percayakan kepada orang terdekat. Orang terdekat bagi informan yaitu orang tua, saudara, tetangga, dan anaknya yang paling tua. Begitu pula dengan dengan informan $\mathrm{C}$, yang tidak perlu merasa khawatir saat balitanya tidak berada di dalam rumah. Berikut kutipan wawancara peneliti dengan informan $\mathrm{C}$ :

"iya. Wong di rumah bu dhenya sendiri kok, Mbak. Ada keponakan saya yang seumuran juga. Baru nanti kalau anaknya ngantuk, baru saya tidurkan di rumah. Saya tinggalkan dulu njaitnya" 
Selain sebagai tetangga terdekat, informan $\mathrm{C}$ merasa aman karena kakak perempuannya tersebut juga ikut mengasuh balitanya sejak kecil. Ia pun terbantu karena pekerjaannya sebagai penjahit dapat tetap dijalankan tanpa rasa khawatir yang berlebihan. Informan $\mathrm{C}$ biasanya akan mengambil balitanya pukul 10 pagi, sebab balita tersebut hampir setiap hari tidur pagi dan sore. Setelah menidurkan balita tersebut, informan dapat melanjutkan pekerjaannya. Kira-kira pukul 1 siang, balita tersebut akan bangun untuk makan siang, lalu kembali tidur sampai pukul 3 sore. Ia pun akan membiarkan anak keduanya tersebut kembali ke rumah 'bu dhe'-nya, sebentara ia mulai membersihkan rumah.

Selain menitipkan balitanya kepada orang terdekat, tidak jarang pula warga Kenjeran juga mengajak balitanya ke tempat ia bekerja. Seperti informan B, seharian penuh ia mengajak balitanya berjualan di THP karena tidak ada yang menjaga anaknya di rumah. Informan E pun kadang membawa balitanya ke tempat pengasapan ikan saat balitanya tidak ingin ditinggal ibunya bekerja. Namun, informan E juga mengaku lebih sering mempercayakan balitanya kepada orang tua, mertua, dan kakak perempuannya. Informan $\mathrm{E}$ hanya bekerja mulai siang sampai sore, sedangkan di pagi hari ia membantu suaminya untuk persiapan melaut. Sejak awal ia sudah membiasakan balitanya bersama orang tua, mertua, dan kakak perempuannya saat ia bekerja, karena mereka juga anggota keluarga dalam satu rumah.

Berbeda dengan informan lain, Informan D sudah membiasakan anak tertuanya agar dapat menjaga adik-adiknya sejak mereka masih kecil. Informan D percaya kepada anak-anaknya, sebab selain mereka sudah terbiasa, informan D hanya bekerja di dalam rumah. Keempat anak perempuannya sudah dianggap mampu untuk saling menjaga satu sama lain, sehingga mereka dapat menjaga satu adiknya yang paling kecil. Selain hal tersebut disampaikan sendiri oleh informan, saat peneliti berkunjung ke rumah informan $\mathrm{D}$, ia sedang mengingatkan anak-anaknya agar menjaga adiknya. Berikut kutipan langsung dari informan D:

"Eh, kakak, itu adeknya dijaga. Jangan main-main. Di rumah aja."

Meskipun informan D bekerja di rumah yang menjual kebutuhan sehari-hari dan menjual gorengan, ia mengaku bahwa dalam menjaga anak keenamnya tersebut ia sering dibantu anakanaknya yang lain. Anak-anaknya sudah diajari bagaimana melayani pembeli dan menjaga adik bungsu mereka saat ia bekerja mempersiapkan gorengan yang akan dijual sore hari.

Kelima informan tersebut hanya memiliki beberapa waktu yang dikhususkan bagi balitanya, yaitu malam hari. Sebab, mulai pagi sampai dengan malam mereka melakukan pekerjaan lain dan mempercayakan balitanya kepada orang lain, baik saudaranya, orang tuanya, atau anak-anaknya yang lain. Berbeda dengan empat informan, satu informan lain, yaitu informan B memiliki intensitas penuh bersama balitanya, sebab ia juga membawa balitanya bekerja mulai pagi sampai dengan sore hari.

Kata "asuh" memiliki makna menjaga, merawat, serta mendidik anak yang masih kecil (Purwadarminta 1976:63). Menurut kamus besar Bahasa Indonesia tersebut, pengasuh tidak hanya mengamankan anak dari wabah penyakit dan upaya-upaya pemenuhan kebutuhan pangan saja, tetapi juga mendidik dan memberi pengetahuan mengenai nilai dan norma yang berlaku di masyarakat. Pola asuh termasuk dalam proses sosialisasi keluarga pada anggotanya. Perilaku berulang akan diajarkan secara turun menurun, seperti pengalaman mereka selama diasuh waktu kecil oleh orang tua, saudara, dan orang-orang di sekitarnya. Dalam penelitian ini pola asuh ibu terhadap anaknya lebih banyak pada waktu malam hari saja.

Para informan dalam penelitian ini mengaku bahwa orang pertama yang mengajari mereka bagaimana mengasuh anak adalah orang tua. Orang tua juga menjadi sumber pengetahuan utama 
tentang kesehatan balita sejak awal kehamilan sampai melahirkan. Orang tua pula yang selalu memberi nasihat, saran dan mengarahkan seputar apa saja yang harus mereka lakukan jika nanti sudah melahirkan. Baik orang tua maupun mertua, nasihat dan ilmu dari mereka cenderung lebih mudah dipercaya dan praktikkan sebab begitulah dulu cara orang tua mengasuh mereka, sehingga, tidak sulit menerapkan ajarannya setelah tahu bahwa dirinya saat ini adalah hasil dari pengasuhan orang tua informan sendiri.

Dulu, demi memastikan anak-anak informan mendapat perlakuan dengan benar, orang tua rela tinggal satu rumah dengan mereka beberapa saat. Orang tua yang sudah mulai menjaga mereka saat bersalin mulai memberi contoh bagaimana cara memandikan dan menyuapi bayi. Setelah informan dapat mengerjakannya secara mandiri, sesekali orang tua informan berkunjung ke rumah untuk menengok balita tersebut, untuk memastikan sudah tepat atau belum.

Saat peneliti melakukan wawancara dengan informan E, ia mengiyakan bahwa orang tua adalah sumber pengetahuan awal bagaimana ia harus memperlakukan bayinya. Informan E dapat dengan baik menceritakan bagaimana ia bersungguh-sungguh menjaga kesehatan bayi pertamanya. Informan E yang baru menikah lima tahun lalu tinggal satu rumah dengan mertuanya, hingga saat ini masih berasa harus belajar banyak pada orang tua. Cara orang tua dan mertua mengajarinya sering kali berdasarkan cerita dari mertua tentang masa kecilnya dan masa kecil suaminya. Seperti cara melindungi bayi agar tidak kedinginan, obat-obatan, dan cara memberi makan. Selain berdasarkan cerita masa lalu dari pengalaman orang tua dan mertuanya, informan E juga sering mendapat nasihat bagaimana harusnya menjadi seorang ibu. Hal tersebut seperti dalam kutipan berikut:

“... kalau mandi harus pakai air hangat biar gak masuk angin, terus dikasih minyak angin biar gak masuk angin. Kalau makan juga harus telaten dibikin sampai lembut. Sampai kalau sakit ini obatnya apa, sakitnya itu obatnya apa gitu, Mbak."

Sama seperti informan E, informan A, B, C, dan D pun memiliki pengalaman yang sama sebelum melahirkan anak pertama mereka. Sebagai anak perempuan yang tinggal tidak jauh dari orang tua dan mertuanya, mereka banyak dibekali ilmu jika nanti sudah memiliki anak. Selain memandikan dengan air hangat dan melumuri tubuh bayinya dengan minyak angin, memberi contoh cara membedong yang rapi, orang tua pula yang pertama kali menyuapi anak mereka saat baru lahir.

Para orang tua informan meyakini bahwa balita yang diberi makanan tambahan selain ASI akan lebih tahan sakit daripada yang hanya mendapat asupan ASI dari ibunya. Makanan tambahan yang diberikan pertama kali saat bayi baru lahir adalah pisang. Pisang yang digunakan adalah pisang hijau, karena pisang tersebut memiliki tekstur yang lembut sehingga mudah ditelan oleh bayi. Biasanya, bayi berumur satu hari baru diberi pisang yang sudah dilembutkan. Mereka melakukannya agak perut bayi menjadi pasek, kondisi yang menyebabkan perut tahan terhadap makanan-manakan padat lain yang nantinya akan menjadi makanan tambahan setelah pisang. Seperti yang dikutip dalam wawancara dengan informan C:

“... Biar pasek itu, Mbak. Nanti kalau perutnya sudah kuat karena sudah biasa diberi makanan padat, itu bagus. Kalau ASI saja kan itu cair.”

Berbagai masalah kesehatan rawan sering terjadi pada balita. Penyakit yang diderita balita pun cenderung beragam jenis dan lamanya diderita. Masyarakat setempat memiliki cara tertentu agar balita yang menderita penyakit bermacam-macam dalam jangka waktu lama dapat sembuh lebih cepat. Salah satu solusi yang dipercaya dapat mengatasi masalah tersebut, masyarakat meyakini bahwa anak bayi yang sakit-sakitan harus dibuang agar dia diasuh orang lain. Selain membuang anak agar ditemukan orang lain dan diasuh oleh si penemu, masyarakat juga percaya bahwa dengan mengganti nama dapat meringankan penyakit yang diderita balita tersebut. Mengganti 
nama dianggap dapat meringankan beban sakit balita karena ia memikul makna namanya yang terlalu berat.

Salah satu solusi tersebut pernah dilakukan oleh informan A, yaitu membuang balita agar ditemukan orang lain. Dulu anak keenamnya sakit-sakitan, setelah sembuh dari satu penyakit, tidak lama kemudian berganti menderita penyakit yang lain, begitu seterusnya. Informan A akhirnya melakukan saran orang tuanya. Ia meletakkan anaknya di depan rumah, lalu ia meminta keponakannya mengambil anak tersebut. Sebelumnya, rencana ini sudah disepakati oleh keluarga besar dan skenarionya sudah dirembuk bersama. Keponakan informan A pun bersedia menjadi orang yang mengambil balita tersebut, yang nantinya balita tersebut akan memanggilknya ibu. Setelah anak bungsunya ia berikan kepada keponakannya sendiri, ia merasa bahwa kondisi putrinya tersebut jauh lebih baik dibandingkan dengan sebelumnya. Sebagai anak yang menuruti saran orang tua dan masyarakat disekitarnya, ia menganggap keputusan tersebut benar. Berikut kutipan wawancara dengan informan A:

"Saya ikuti saja saran orang tua, mereka kan jauh lebih mengerti dari saya. Alhamdulillah, setelah itu Nurul sehat. Meskipun sudah terlanjur kena radang usus, tapi anaknya itu kelihatan lebih sehat. Bener juga orang-orang tua itu, Mbak."

Informan $\mathrm{E}$ adalah informan yang paling muda di antara informan lain. Ia berusia 25 tahun, sedangkan saat ini ia baru memiliki 1 orang anak. Informan $\mathrm{E}$ baru menikah 5 tahun yang lalu, dan dua tahun kemudian ia menjadi ibu. Selain dari wawancara yang dilakukan peneliti dengan informan, peneliti pun mengamati bagaimana orang tua atau mertua informan tersebut sebagai sumber pengetahuan mereka tentang kesehatan bagi informan E. Beberapa kali saat peneliti berkunjung ke rumah informan E yang tinggal satu rumah dengan orang tuanya, sering kali peneliti melihat nenek tersebut menyuapi cucunya sambil bercerita kisah-kisah masa lalu dengan cucunya. Sempat pula peneliti berada di rumah informan E sore hari, menyaksikan informan E dimarahi oleh ibunya karena anak tersebut belum makan siang. Hal ini menunjukkan bahwa kepedulian orang tua para informan terhadap balita informan seperti mereka peduli dengan anak mereka sendiri. Apa yang dulu ibu mereka lakukan pada anak-anaknya, kini setelah mereka sudah menjadi ibu, diulang lagi dan diterapkan pula pada anak-anaknya.

Orang tua juga mengajarkan bahwa anak-anak jangan sering dipaksa, sebab itu akan membuat anak kurang senang hatinya, sehingga anak lebih sering murung dan tidak dekat dengan orang tua. Hal tersebut diungkapkan oleh informan A, B, C, dan D. Berbeda dengan yang lain, informan E justru lebih sering memaksa pada anaknya, termasuk soal asupan makanan.

Kebudayaan dibutuhkan manusia sebagai sarana untuk beradaptasi dengan lingkungan mereka. Kebudayaan mengacu kepada pengetahuan yang diperoleh individu dan digunakan untuk menginterpretasikan pengalaman dan melahirkan tingkah laku sosial (Spradley 1997:5). Pengetahuan informan tentang cara mengasuh dan menjaga kesehatan masih banyak diwarnai kepercayaan dan mitos. Niven (2002:299-300), seorang pakar Psikologi Kesehatan mengutarakan bahwa budaya berpengaruh langsung dalam kesehatan, sebab budayalah yang mempengaruhi perilaku sehat. Pengasuhan anak memiliki ciri khas yang diajarkan turun-temurun (Koentjaraningrat 1979:119).

\section{Simpulan}

Simpulan dari penelitian ini berdasarkan apa yang kami temukan adalah bahwa perhatian pada anak dari kelima informan yang mempunyai balita dengan berat badan di Bawah Garis Merah (BGM), mereka tidak mempunyai waktu yang cukup untuk merawat anaknya. Sementara orang yang merawat balita mereka belum tentu memerhatikan bayi yang dititipkan itu dengan baik. 
Lima informan mengaku bahwa waktu yang mereka berikan untuk balita mereka adalah pada waktu malam hari.

Masalah lain dari para informan yang mempunyai balita dengan berat badan di Bawah Garis Merah (BGM) adalah belum baiknya pengetahuan tentang pengasuhan anak, termasuk kepercayaan terhadap masalah kesehatan sering dikaitkan dengan nama yang tidak cocok atau hal lain yang sebenarnya secara ilmu kesehatan tidak terkait. Sebagai contoh, salah satu solusi dengan cara pura-pura membuang anaknya agar ditemukan oleh seseorang, agar terhindar dari penyakit dan kesialan.

Praktik pemberian makanan padat pada bayi masih serng dilakukan di daerah ini, yang mana dipercaya lebih bagus dari pada pemberian ASI saja. Padahal secara medis hal ini tidak disarankan, karena bayi mempunyai umur minimal untuk dapat menerima makanan padat sebagai tambahan dari ASI.

\section{Daftar Pustaka}

Moehji S (2003) Ilmu gizi penanggulangan gizi buruk. Jakarta: Papas Sinar Sinanti Arisman (2004) Gizi dalam daur kehidupan. Jakarta: ECG.

Purnomo PS (2002) Pengalaman fortifikasi tepung terigu di Indonesia. Dalam: Hardinsyah LA dan Setiawan B (ed). Fortifikasi Tepung Terigu dan Minyak Goreng. Pusat Studi Kebijakan Pagan dan Gizi (PSKPG) IPB, Komisi Fortifikasi Nasional (KFN) ADB-Manil dan Keystone Center-USA. 49-53.

Poerwadarminta WJS (1976) Kamus umum Bahasa Indonesia. Jakarta: Balai Pustaka.

Spradley JP (1997) Metode etnografi. Yogyakarta: Tiara Wacana Yogya.

Niven N (2002) Psikologi kesehatan. Jakarta: Penerbit Buku Kedokteran EGC.

Koentjaraningrat (1979) Pengantar ilmu antropologi. Jakarta: PT. Rineka Cipta. 